\title{
ADDIE educational technology for coursework design in environmental education for sustainable development in Russia
}

\author{
Natalya Ryazanova ${ }^{1, *}$, Anna Semak $^{2}$, Ekaterina Kazakova ${ }^{2}$ \\ ${ }^{1}$ Moscow State Institute of International Relations (MGIMO University), 119454, 76 Vernadskogo \\ prospect, Moscow, Russia \\ ${ }^{2}$ Russian State Agrarian University - Moscow Timiryazev Agricultural Academy (RSAU-MSAA) \\ named by K.A.Timiryazev, 127550, 49 Str. Timiryazevskaya, Moscow, Russia
}

\begin{abstract}
The aim of the work is to conduct a comparative analysis of the national goals and objectives in the national project "Ecology" and the global SDGs. This article considers he main vectors of environmental discourse, their compliance with the international agenda and relevance for various regions of RussiaThe work presents the course results designed according to the classical model ADDIE. An educational strategy and a public environmental information model have been established.. Small groups of students (12) were set up to work on researching selected federal projects from the national project. The research was conducted according to the unified plan and was designed with different content for each group of students, which allowed a comprehensive evaluation of the "Ecology" project. Each group of researchers analyzed the main goals and objectives of the federal projects, conducted a comparative analysis between the global SDGs and features of the national plan to achieve them. The analysis showed that the goals should be adjusted as they are achieved. The technique tested allows to implement a widespread application in an environmental education and investigate the large management models in the natural resource management.
\end{abstract}

\section{Introduction}

Since 2018, Russia has introduced the project management in the environmental and natural resource management. Among the twelve main national projects there was a national project "Ekologia" (or "Ecology"), which included twelve key federal projects in the areas: forest management, waste management, clean air, biodiversity, clean water and sanitation, unique water bodies, forest conservation and others. To master the project concept in the environmental management, new approaches in the training of environmental scientists need to be developed. Studying the project-based management approach required a project-based learning approach. For this purpose, we analyzed several models of training course design: ADDIE, ASSURE, SAM 1 and SAM 2. The learning

\footnotetext{
* Corresponding author: natamgimo@gmail.com
} 
objective was to examine the composition of the goals and objectives of each federal project in respect to their relevance to the global SDGs, as well as the characteristics of the state of the industry to which each federal project is dedicated. Students should be able to learn how to define multiple-level objectives, conduct a literature research and analyze large data sets, , apply analytical skills, handle a research design, and present their final results in a concise and coherent manner. All stages of the work should be done according to the project approach, i.e. the goals set at each project stage, the scope of research is defined, the deadlines and the expected results of the project are set including educational ones. The innovation of the work lies in the absence of a contracting and accepting party. All these functions are fulfilled by the university professor who develops such a project course. Under this approach, the course can be seen as a model course and, if it is well worked out and elaborated, it can be scaled to different academic disciplines.

\section{Methods and materials}

The project approach in training provides students with a reduced period of adaptation in the workplace after graduation, which is important for the employer and helps reduce the costs of instructing a new specialist. The projects in training can be short-term (2-3 credits, duration:one semester) and long-term (up to 6-8 credits, duration: 1-1.5 academic years) [1]. The best project works are to be created under the guidance of customers from the real economic sectors, then they are as close to the real professional tasks [2]. The customer not only provides with the research topic but also indicates the possible research directions, the depth of the topic analysis, and recommends some information sources along with the dates of the deadlines. Upon completion, such projects will be presented as a scientific poster or Power Point presentation and defended with a report before an expert committee. The students, who present the best solutions to the given case study could get a job as an intern in the customer organization or even get a full-time position. This approach has proved itself globally and is widely used by companies to recruit and brainstorm original ideas that may need further elaboration. [3].

The work carried out at the MGIMO University in 2020, implemented the development of a model project approach in environmental education in the form of the classic ADDIE design model (Fig. 1). The model was developed in 1975 and showed versatility [4], simplicity and consistency [5] and made it possible to achieve the educational result within a set learning period (Table 1) - during one semester [6]. Each project group received a different subject of study, but all project groups worked according to the same plan and had the same deadlines. In this approach it is possible to compare the quality of the obtained analytical material and make a relevant assessment of the obtained educational result.

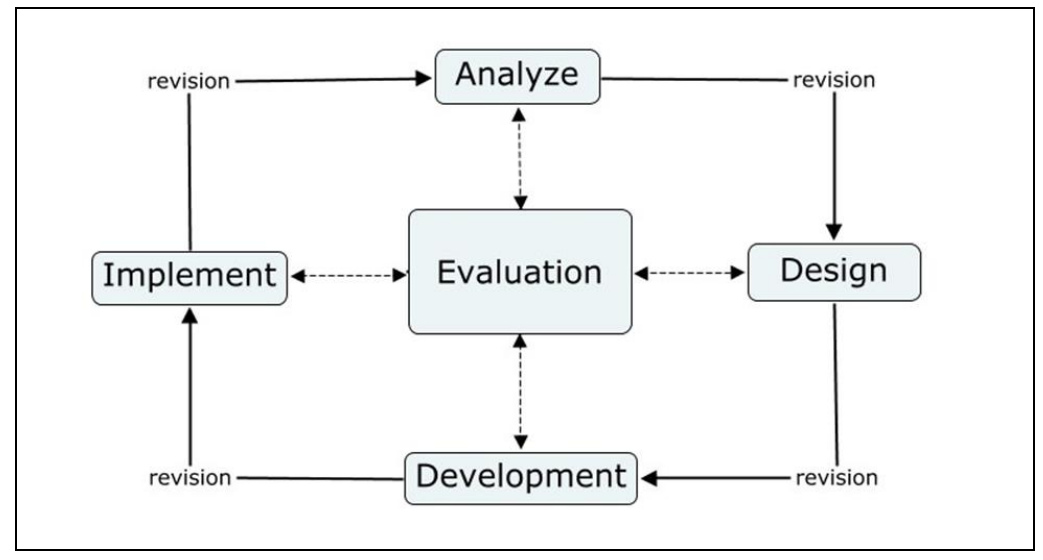


Fig. 1. Diagram of the ADDIE design model implementation.

Table 1. Implementation of the ADDIE design model for environmentalist training.

\begin{tabular}{|c|c|c|}
\hline Design stage & Key steps & Educational outcome \\
\hline \multirow[t]{3}{*}{ A nalysis } & $\begin{array}{l}\text { Identification of } \\
\text { the educational } \\
\text { goals }\end{array}$ & $\begin{array}{l}\text { What to teach? How deeply? What results do we want to } \\
\text { achieve? } \\
\text { Analysis of students' background knowledge and skills. } \\
\text { Analysis of training courses prior to the project course, what } \\
\text { students have already learned and what skills they possess. } \\
\text { How do the global SDGs relate to Russia's national goals? } \\
\text { What skills are needed? What should students learn? What } \\
\text { skills should they have developed? What learning goals is } \\
\text { the project aimed at? Which learning environment is more } \\
\text { suitable online or offline? What limiting factors might arise? } \\
\text { Will students have enough technical skills? } \\
\text { What kind of support from the instructor might be needed? }\end{array}$ \\
\hline & $\begin{array}{l}\text { Development of } \\
\text { an educational } \\
\text { strategy }\end{array}$ & $\begin{array}{l}\text { Choose the form of the course: it can be a project approach } \\
\text { and online control. } \\
\text { How the course should be structured, so that it has stages of } \\
\text { learning and obtained educational results in each of them. }\end{array}$ \\
\hline & $\begin{array}{l}\text { Study the target } \\
\text { audience }\end{array}$ & $\begin{array}{l}\text { It is necessary to understand how well the students know the } \\
\text { content of the SDGs and understand which specific national } \\
\text { goals to compare with, whether they understand how to } \\
\text { compare the goals qualitatively and quantitatively at } \\
\text { different levels of their setting - how to move from the } \\
\text { global level to the national level. }\end{array}$ \\
\hline \multicolumn{3}{|c|}{ Final briefing on stage $\mathrm{A}$} \\
\hline \multirow[t]{2}{*}{ D esign } & \multirow{2}{*}{$\begin{array}{l}\text { Creationa } \\
\text { thematic plan: } \\
\text { Creation of } \\
\text { training } \\
\text { modules } \\
\text { Creation lessons } \\
\text { Creation } \\
\text { assessment } \\
\text { materials }\end{array}$} & $\begin{array}{l}\text { Objectives are defined, subject content analysis, tools: } \\
\text { assignments and exercises, assessment materials, lesson } \\
\text { planning, and other resources. }\end{array}$ \\
\hline & & $\begin{array}{l}\text { Determine the time to complete each step. } \\
\text { Formulate what knowledge and skills emerge after each } \\
\text { stage. } \\
\text { Develop different variations of assessment materials: } \\
\text { geographic maps, mental maps, practical tasks, creating your } \\
\text { own analytical texts, creating interim and final presentations } \\
\text { and a report to the experts. } \\
\text { Develop feedback mechanisms individually and with the } \\
\text { group. } \\
\text { Determine the main idea of the project. }\end{array}$ \\
\hline \multirow[t]{2}{*}{ D evelopment } & $\begin{array}{l}\text { Decision on the } \\
\text { content: text, } \\
\text { presentations, } \\
\text { videos, etc. }\end{array}$ & $\begin{array}{l}\text { Monitoring the adherence to time limits on both the creation } \\
\text { of the course assignments and their completion by students. } \\
\text { Assessment of individual and team work, assessment of the } \\
\text { whole group. } \\
\text { Whether all students are working to their full potential, not } \\
\text { shifting responsibilities to other team members. }\end{array}$ \\
\hline & $\begin{array}{l}\text { Creation of a } \\
\text { test or control } \\
\text { lesson }\end{array}$ & $\begin{array}{l}\text { Instructional session, in which all stages of work and their } \\
\text { filling are voiced and visualized. Produced if necessary at } \\
\text { different stages of the work. }\end{array}$ \\
\hline \multirow[t]{2}{*}{ I mplementation } & $\begin{array}{l}\text { Taking the } \\
\text { course on your } \\
\text { own }\end{array}$ & \multirow{2}{*}{$\begin{array}{l}\text { Evaluating individual modules and the entire course, making } \\
\text { edits, and getting feedback. } \\
\text { Development of backup tools if there are problems with the } \\
\text { implementation of the thought-out training strategy. } \\
\text { Willingness to change the scope of the study if the planned }\end{array}$} \\
\hline & $\begin{array}{l}\text { Taking a course } \\
\text { with a guidance }\end{array}$ & \\
\hline
\end{tabular}




\begin{tabular}{|l|l|l|}
\hline & $\begin{array}{l}\text { counselor or } \\
\text { tutor }\end{array}$ & $\begin{array}{l}\text { depth of immersion in the topic or communication with } \\
\text { specific experts does not work out. } \\
\text { Evaluate whether students are working independently or } \\
\text { only in groups. Which approach is more effective? Is it } \\
\text { supportive connections or substitute connections? }\end{array}$ \\
\hline $\begin{array}{l}\text { Passing with a } \\
\text { test group }\end{array}$ & $\begin{array}{l}\text { Students' } \\
\text { assessment } \\
\text { E valuate }\end{array}$ & $\begin{array}{l}\text { Howative stage: students' work on the project, meeting } \\
\text { Testing, etc. }\end{array}$ \\
\cline { 2 - 3 } & $\begin{array}{l}\text { Self-evaluation } \\
\text { of the teacher } \\
\text { himself }\end{array}$ & $\begin{array}{l}\text { Summary stage: whether the goals are achieved, how to } \\
\text { improve and promote the course to other disciplines, to scale } \\
\text { it, to increase the efficiency and success of the project. }\end{array}$ \\
\hline
\end{tabular}

To implement the project-based learning task [8], we needed 1) an array of inputs: course developer professor, students, learning content, teaching methodology, course strategy; 2) process: creating the curriculum, content systematization, project implementation roadmap; 3 ) result: project implementation by a group of students, their acquisition of a professional skill.

\section{Results}

The work on the project began in offline mode, when the entire group listened to an introductory briefing about the types, technologies, and deadlines for the work (Table 2). The work then went online due to quarantine restrictions.

A course of students was divided according to their own preferences into 12 work groups, each of which studied work tasks on one of the 12 federal projects that are part of the National Ecology Project. The general title of the work was the same for all of them "Analysis of the project management capabilities within the framework of the federal project "...name of one of the 12 projects...", which is a part of the national project "Ecology".

Table 2. Implementation of course design in environmental students in the technology of ADDIE project model

\begin{tabular}{|l|l|}
\hline $\begin{array}{c}\text { Design } \\
\text { stage }\end{array}$ & \multicolumn{1}{c|}{ Achieving an educational outcome } \\
\hline A nalyze & $\begin{array}{l}\text { The analysis of the entrance knowledge and skills of students was carried out. It } \\
\text { was revealed that in the } 2^{\text {nd }} \text { year they knew more than 4-5 natural-science } \\
\text { disciplines but there is still no knowledge of management processes in nature } \\
\text { management. Available skills that students have: work with databases of refereed } \\
\text { articles, Garant-plus, Consultant-plus, the ability of an expanded independent } \\
\text { literature research and regulatory frameworks, work with databases. Within the } \\
\text { framework of the } 1^{\text {st }} \text { year academic practice an idea of how global SDGs relate to } \\
\text { the national goals of Russia is formed. Students must learn how to correlate federal } \\
\text { project performance targets so that they can be correlated with global SDGs. The } \\
\text { coursework project is designed to develop project work skills, the ability to meet } \\
\text { project deadlines, and the ability to work in small groups and be collectively } \\
\text { responsible for the final outcome. The project is implemented in an online learning } \\
\text { environment. }\end{array}$ \\
\cline { 2 - 3 } & $\begin{array}{l}\text { Choose the form of the course: } \\
4 \text { thematic modules; control activities after each module; feedback from working } \\
\text { groups; course adjustment. }\end{array}$ \\
\cline { 2 - 3 } & $\begin{array}{l}\text { It was found that the students are aware of the content of the SDGs and understand } \\
\text { how the analysis of national goals and SDGs, which they have chosen for their } \\
\text { study, has to be conducted. }\end{array}$ \\
\hline
\end{tabular}




\begin{tabular}{|c|c|}
\hline & $\begin{array}{l}\text { Preliminary briefing revealed that all working groups understand how to compare } \\
\text { goals qualitatively and quantitatively at different levels of goal setting:how to move } \\
\text { from the global level to the national level. }\end{array}$ \\
\hline \multirow[t]{2}{*}{ D esign } & $\begin{array}{l}\text { Developed methodological recommendations (in the form of a presentation to } \\
\text { instruct the course), which contain goals, analysis of the content of the subject, } \\
\text { tools: tasks and exercises, assessment materials, lesson planning and other } \\
\text { resources. }\end{array}$ \\
\hline & $\begin{array}{l}\text { Deadlines for each stage are set. Knowledge and skills after each stage of design are } \\
\text { formulated. Different variations of assessment materials were developed: } \\
\text { geographic maps, mental maps, practical tasks, creating own analytical texts, } \\
\text { creating intermediate and final presentations and a report to the experts. Feedback } \\
\text { mechanisms for individual and group feedback were provided via Google Docs and } \\
\text { email. Periodically, as part of the discipline classes, there was an exchange of } \\
\text { opinions on the course of the current stage of the project. The main idea of the } \\
\text { project was defined as the ability to work in a project team, create analytical } \\
\text { materials and analyze them for compliance with the SDGs. }\end{array}$ \\
\hline \multirow[t]{2}{*}{ D evelop } & $\begin{array}{l}\text { A roadmap for the project was created. Its implementation was monitored by the } \\
\text { date the finished work phase (document or test material) was posted on Google } \\
\text { docs. } \\
\text { Assessment of individual and collective work was carried out on the distribution of } \\
\text { the author's contribution, which indicated the authors themselves and on individual } \\
\text { maps and tests from each participant in the project, the assessment of the entire } \\
\text { group - on the date of closure (performance) of the next stage of work. }\end{array}$ \\
\hline & $\begin{array}{l}\text { Conducted an instructional session, in which all the stages of work and their filling } \\
\text { are voiced and visualized. }\end{array}$ \\
\hline I mplement & $\begin{array}{l}\text { Evaluation of individual modules and the entire course, edits and getting feedback. } \\
\text { Backup tools for project implementation were not developed because of the need to } \\
\text { adapt to online learning. It was not necessary to change the scope of the study, there } \\
\text { were meetings with almost all the experts. Evaluate whether the students could } \\
\text { work independently or only in groups. }\end{array}$ \\
\hline \multirow[t]{2}{*}{$\mathbf{E}$ valuate } & $\begin{array}{l}\text { Formative stage: students' work on the project, fulfillment of deadlines and filling } \\
\text { the content of the blocks. The motivation of students was increased by meetings } \\
\text { with experts - the heads of the project offices of the Ministry of Natural Resources } \\
\text { and Environment of Russia. }\end{array}$ \\
\hline & $\begin{array}{l}\text { Summing up: the goals have been achieved. } \\
\text { It makes sense to scale the project approach to other academic disciplines. }\end{array}$ \\
\hline
\end{tabular}

During the orientation, the students were presented with a roadmap of project stages and deadlines (Figure 2). It was indicated that the entire course should move at the same pace with the presentation of the same outcomes for each stage, but with their own content.

To improve the quality of acquaintance with the initial data and approaches to the project work, weekly expert lectures were held with the heads of the project offices of specific federal projects. The experts presented the details of the project work in their professional area, disclosed the stages of work, the difficulties, and limitations of project goals implementation in various regions, and analyzed the problems. At the end of each expert's presentation, the students had the opportunity for a briefing where they could ask specific questions that they themselves had not been able to figure out. This approach with weekly verification of the study helped not to deviate from the goals and objectives of the project teams and improve the quality of the final content of the project work.

\section{Analysis}

In the process of coursework design the students developed skills of project management, working in small groups, sharing collective responsibility, meeting deadlines of each project stage, interviewing industry experts. Stages of work were rather long, which 
allowed the students to cope not only with the coursework design but also with other semester disciplines. It was possible to create the skill set necessary for analysis of current public works in the field of ecology and environmental management in terms of compliance with the objectives of the national goals to the global. Such a skill set is currently lacking in modern officials and should be formed in the younger generation as a result of the implementation of education for sustainable development [9].

\begin{tabular}{|c|c|}
\hline \multicolumn{2}{|c|}{$\begin{array}{l}\text { Step 1: Review of the theoretical basis for the federal project } \\
\text { (1 month) }\end{array}$} \\
\hline \multicolumn{2}{|c|}{$\begin{array}{l}\text { Stage } 2 \text { : Interim results of the federal project } \\
\qquad(1 \text { month) }\end{array}$} \\
\hline $\begin{array}{l}\text { Review of the methods of monitoring the } \\
\text { implementation of the federal project. Intermediate } \\
\text { results of the federal project in the regions of Russia }\end{array}$ & $\begin{array}{l}\text { Control work 2. Objects and mechanisms of the federal } \\
\text { project }\end{array}$ \\
\hline \multicolumn{2}{|c|}{$\begin{array}{l}\text { Step 3: Recommendations for optimizing the federal project } \\
\qquad(1 \text { month) }\end{array}$} \\
\hline $\begin{array}{c}\text { Cases of implemented targets for the current year in } \\
\text { the regions of Russia }\end{array}$ & $\begin{array}{l}\text { Control work No. 3. Critique and vectors to optimize } \\
\text { the implementation of the federal project }\end{array}$ \\
\hline \multicolumn{2}{|c|}{ Step 4: Presentation of the results of the project work(1 month) } \\
\hline $\begin{array}{l}\text { The final version of the work. Preparation of the } \\
\text { presentation. Preparation of the report. }\end{array}$ & $\begin{array}{c}\text { The project team's report and presentation to the } \\
\text { expert community. }\end{array}$ \\
\hline
\end{tabular}

Fig. 2. Roadmap of the project work of the working groups.

Some limitations: because of the abrupt transition to online learning format, it turned out that some students lacked technical skills to work with databases or those skills were very uncertain; some students coped very poorly morally due to the lack of their peers' support some found it quite difficult to address questions to the teacher, got stressed by the possibility of disruption of stage deadlines. In addition, it was not possible to organize meetings with the heads of those project offices that are not part of the Ministry of Natural Resources and Environment, they did not see the possibility of such meetings, especially online, with little or no comment. This hampered the work of the project teams working on these projects and did not allow them to make their work more practice-oriented. 


\section{Summery}

The results of the work in the ADDIE design model were presented at several international conferences. Participants of conferences - professors, teaching ecologists, confirmed the difficulty and sometimes impossibility of inviting experts from the industry to students, their reluctance to share their expertise and complete lack of understanding of the need for practice-oriented training of students, for fear of soon competition with them in the labor market. This work confirmed some theses: it was not possible to find at least a conditional "customer" in the person of not only the Ministry, but also any of its departments. Thus, the weak link in the work of the Ministry was revealed, i.e. the absence of the target order for personnel training in specific areas of activity. As a result, the professor had to build an ideal model of project work, which, however, clearly succeeded and can be finalized for other disciplines, except for the approved Fundamentals of Nature Management module.

\section{Conclusion}

Students are taught the skills of project work in a short period of time - during one academic semester. theoretical knowledge is supported by the practice of implementing their own project. The skill formed will be in demand by students within the framework of both research works, and in practice and internships.

\section{References}

1. M.A. Manokin, A.R. Ozhegova, E.A. Shenkman, University Management: Practice and Analysis, 22(4), 83-96 (2018)

2. A. Sureka, M. Gupta, D. Sarkar, V. Chaudhary, 1st International Workshop on Case Method for Computing Education (CMCE 2015). CEUR-WS.org, 1519, 15 (2015).

3. A. Chun, Lecture Notesin Computer Science LNCS - Advances in Web-Based Learning, 3143, 11-18 (2004)

4. S. Kurt, Educational Technology, August 29 (2017). Retrieved from https:/educationaltechnology.net/the-addie-model-instructional-design/

5. S. Kurt, An Introduction to the ADDIE Model: Instructional Design: The ADDIE Approach (Kindle Edition, 218)

6. Z.Masood, R. Hoda, K. Blincoe, The J. of Systems and Software, 144, 501-510. (2018)

7. Materials from the Educational Technology website. The ADDIE model: instructional design. URL: https://educationaltechnology.net/the-addie-model-instructional-design/

8. I. Noguera, A.-E. Guerrero-Roldan, R. Maso, Computers and Education, 116, 110-129 (2018).

9. G.M. Abdurahmanov, N.O. Gusejnova, Yu.Yu. Ivanushenko, S.V. Prokopchik, D.I. Kadieva, Z.I. Soltanmuradova, South of Russia: ecology, development, 12(3), 115-137 (2017) 